\title{
PENGIMPLEMENTASIAN DANPERANCANGAN SISTEM INFORMASI PENGONTROLAN PEMAKAIAN RUANG INAP PUSKESMAS MUARO KIAWAI KEC. GUNUNG TULEH JAMBI
}

\author{
Sophan Sophian \\ Dosen STMIK Indonesia Padang \\ Ophan@stmikindonesia.ac.id
}

\begin{abstract}
In the development of information technology adult is really needed skill, the ability and resources that broad thought to confront the developments that are rapidly increasing .So also with every aspect of life at Indonesia today.Although most on the respective regions in indonesia having different geographical but we should have a system that kept changing. On regions Muaro Kiawai Kec .Jambi Gunung Tuleh Puskesmas that there is not yet have a system of information that can help officers as well as nurses take care of there to generate reports as well as perform the process of rapid penginputan. And was development in a system that can ease duty nurse there. Both in data entry process room, patient data and data doctors. Once learned, the authors draw the conclusion that in applying the computerized system in this case, Programming Language Visual Basic and Database MySQL is the appropriate application, because these applications is very easy in the process of transactions and reports.
\end{abstract}

Keywords : Information Technology, Data Information, Reports

\section{Pendahuluan}

Komputer merupakan salah satu bagian dari kemajuan teknologi informasi. Banyak instansi yang telah menggunakan komputer sebagai alat bantu untuk sistem pengolahan datanya, dengan tujuan agar pekerjaan dan masalah yang ada dapat diatasi dengan cepat dan akurat, serta keterlambatan informasi atau laporan dapat dihindari.

$\begin{array}{lrr}\text { Komputer juga } & \text { merupakan alat } \\ \text { atau sarana untuk } & \text { mempermudah } \\ \text { pekerjaan } & \text { pada } & \text { bidang } \\ \text { pengadministrasian pada } & \text { suatu instansi } \\ \text { atau lembaga-lembaga. Kemajuan dan }\end{array}$

perkembangan teknologi informasi yang sangat kompleks dan bervariasi.

Informasi yang ada dapat dikelola dengan memakai komputerisasi, baik berupa data-data maupun laporan bisa diprogram dengan menggunakan komputer. Dapat kita ambil contoh di Puskesmas Muaro Kiawai Kec. Gunung Tuleh Jambi, walaupun dirumah sakit ini memiliki komputer tetapi hanya digunakan untuk mengetik seperti surat atau laporan, tetapi untuk sistem informasi tentang data ruang inap masih menggunakan sistem manual, yaitu berupa dokumen berbentuk kertas sangat 
terkesan lambat bila dibandingkan dengan menggunakan sistem komputerisasi.

Seiring dengan perkembangan teknologi itu sendiri, maka untuk memudahkan dan membantu dalam proses pengontrolan ruang inap di Puskesmas Muaro Kiawai Kec. Gunung Tuleh Jambi perlu di dukung dengan sistem komputerisasi yaitu dengan suatu bahasa pemograman, sehingga dapat diolah dan di gunakan secara optimal.

Dengan adanya sistem yang baru di harapkan agar dapat mempermudah proses pengontrolan ruang inap di Puskesmas Muaro Kiawai Kec. Gunung Tuleh Jambi yang di lakukan dari sistem berupa dokumen ke sistem komputerisasi yang menggunakan bahasa pemograman, untuk mencegah terjadinya kesalahan dalam mengontrol ruang inap, dan dapat memudahkan untuk mencari data dan arsip apa bila di butuhkan lagi.

Dari permasalahan diatas penulis tertarik untuk melakukan penelitian lebih lanjut dengan judul "Sistem Informasi Pengontrolan Pemakaian Ruang Inap Puskesmas Muaro Kiawai Kec. Gunung TulehJambi”.

Dimana nantinya diharapkan dapat membantu mempercepat dalam mengontrol pemakaian ruang inap, sehingga pelaksanaan pembangunan dibidang kesehatan dapat dilakukan dengan baik".

\subsection{Perumusan Masalah}

Berdasarkan latar belakang masalah, identifikasi masalah, dan batasan masalah maka penulis dapat merumuskan masalah sistem informasi pengontrolan pemakaian ruang inap Puskesmas Muaro Kiawai Kec. Gunung Tuleh Jambi adalah masalah mengontrol pemakaian ruang inap. Dalam hal ini penulis melakukan penelitian yaitu bagaimana merancang suatu sistem informasi pengontrolan pemakaian ruang inap Puskesmas Muaro Kiawai Kec. Gunung Tuleh Jambi..

\section{METODOLOGI}

\subsection{Konsep Dasar Perancangan Sistem}

Sistem merupakan kumpulan elemen-elemen yang saling terkait antara satu dengan yang lain yang tak dapat dipisahkan, untuk mencapai satu tujuan tertentu. Oleh karena itu dalam membangun sebuah sistem kita harus paham konsep dasar dari sistem itu sendiri.

\subsubsection{Arti Perancangan Sistem}

Perancangan sistem didefinisikan oleh Robert J.Verzello atau Jhon Ruler III dalam bukunya "Data Processing : System and Concept", yaitu :

"Tahap setelah analisis dan siklus pengembangan sistem adalah pendefinisian dari kebutuhankebutuhan fungsional dan persiapan untuk rancang bangun implementasi yaitu : suatu sistem dibentuk".

Menurut George M.Scott dalam bukunya yang berjudul "Principles of Management Information System", yaitu

$\begin{array}{llr}\text { "Rancangan } & \text { sistem } & \text { untuk } \\ \text { menentukan } & \text { bagaimana } & \text { suatu } \\ \text { sistem akan } & \text { menyelesaikan apa }\end{array}$

"Rancangan sistem untuk menentukan bagaimana suatu sistem akan menyelesaikan apa 
yang mesti diselesaikan tahapan ini meyangkut mengkonfigurasikan komponenkomponen dari perangkat keras dari suatu sistem sehingga setelah instalasi dari sistem akan benarbenar memuaskan “.

Dengan demikian rancangan sistem dapat diartikan sebagai berikut :

1. Tahap setelah analisis dari siklus pengembangan sistem.

2. Pendefinisian dari kebutuhankebutuhan fungsional.

3. Persiapan untuk rancang bangun implementasi.

4. Menggambarkan bagaimana sistem dibentuk dapat berupa penggambaran, perancangan dan pembuatan sketsa atau pengaturan dari beberapa elemen yang terpisah kedalam satu kesatuan yang utuh dan berfungsi.

5. Termasuk untuk mengkonfigurasikan dari komponen-komponen perangkat lunak dan perangkat keras dari suatu sistem.

\subsubsection{Tujuan Perancangan sistem}

Tahap rancangan sistem mempunyai tujuan utama yaitu :

1. Untuk memenuhi kebutuhan pemakai sistem.

2. Untuk memberikan gambaran yang jelas dan rancang bangun yang lengkap pada Pemrograman komputer dan ahli-ahli teknik yang lainnya yang terlihat.

Kedua tujuan tahap rancangan sistem tersebut lebih cenderung pada rancangan sistem yang terinci yaitu pembuatan rancang bangun yang jelas dan lengkap yang nantinya digunakan untuk mencapai tujuan analisis sistem.

Tahapan perancangan sistem.

1. Mendefinisikan masalah, yaitu menentukan hal-hal apa saja sebenarnya yang menjadi masalah dalam perusahaan sehingga kita dapat menentukan pemecahan yang sesuai.

2. Analisis masalah, yaitu meneliti dengan sebaik mungkin masalah yang sudah ditentukan dan memikirkan alternatif yang terbaik dalam pemecahan terhadap perancangan sistem yang baru saja digambarkan.

3. Perancangan global, yaitu melakukan perancangan global terhadap sistem yang baru dengan menggunakan metode-metode perancangan secara garis besar.

4. Perancangan detail, yaitu dengan menentukan bentuk-bentuk perancangan secara terperinci, dengan menggunakan metodemetode perancangan yang sering digunakan apakah itu desain output, desain input, desain file, struktur program.

5. Program, yaitu membuat rancangan sistem yang baru dengan menggunakan bahasa pemrograman tertentu sesuai dengan aplikasi yang dibutuhkan.

6. Testing, yaitu mengandalkan pengujian terhadap sistem program yang dirancang sesuai dengan keinginan yang dikehendaki dalam perancangan sebelumnya. 
7. Implementasi, yaitu menetapkan program yang telah dibuat kedalam sistem untuk menggunakan program tersebut, apakah sesuai dengan yang diinginkan.

8. Evaluasi, operasi dan perawatan, yaitu melakukan operasi terhadap program dan juga melakukan penawaran secara umum untuk memelihara program yang ada.

9. Dokumentasi, yaitu melakukan penduplikasian data melalui program yang dibuat sehingga apabila sewaktu-waktu terjadi halhal yang tidak diinginkan maka kita dapat mengantisipasinya.

Kualitas dari suatu informasi tergantung pada tiga hal yaitu:

1. Akurat

Informasi yang dihasilkan harus bebas dari kesalahan-kesalahan. Akurat juga berarti informasi harus jelas mencerminkan maksudnya.

2. Tepat pada waktunya

Informasi tepat waktu, karena informasi merupakan landasan di dalam pengambilan keputusan ditingkat manajemen yang lebih tinggi.

3. Relevan

Informasi tersebut mempunyai manfaat untuk pemakainya, Relevansi informasi untuk setiap pemakai yang satu dengan yang lainnya berbeda.

\subsubsection{Sekilas Tentang Visual Basic Net}

Visual Basic pada dasarnya adalah sebuah bahasa pemrograman komputer, bahasa pemgroman adalah peritahperintah atau instruksi-instruksi yang dimegerti oleh komputer untuk melakukan tugas-tugas tertentu.

Visual Basic (yang sering disingkat dengan VB) selain disebut sebagai sebuah bahasa pemograman, juga sering disebut sebagai sarana (tool) untuk menghasilkan program-program aplikasi berbasiskan Windows. Beberapa kemampuan atau dari Visual Basic diantaraya adalah:

1. Untuk membuat program aplikasi berbasiskan Windows.

2. Utuk membuat objek-objek pembantu seperti misalnya Control ActiveX, file help, aplikasi internet dan sebagainya.

3. Menguji program (Debugging) dan menghasilkan program akhir berakhiran exe yang bersifat executable atau dapat lansung dijalankan.

Keuntungan Bahasa Pemograman Visual Basic

Ada beberapa keuntungan dari Visual Basic diantaranya:

1. MS Visual Basic memungkinkan aplikasi pembuatan Graphical User Interface (GUI) atau pemograman yang menggunakan tampilan grafis sebagai alat komunikasi dengan pemakai.

2. Mempunyai fleksibilitas yang sangat baik berhubungan dengan aplikasi yang lain. Kemampuan ini didukung dengan digunakannya Object Linking and Embedding (OLE) yang memungkinkan pembuatan 
hubungan antara bagian fungsi atau dengan seluruh aplikasi lain.

3. MS Visual Basic sangat kompatibel dengan Visual Basic versi terdahulu.

4. MS Visual Basic juga mendukung penggunaan long file name atau nama variabel sampai sepanjang 255 character.

Visual Basic.NET 2010 merupakan salah satu aplikasi pemrograman visual yang dilakukan oleh Microsoft. Visual Basic telah melalui berbagai tahapan pembangunan sejak zaman BASIC yang dibangununtuk DOS. DASAR singkatan All-tujuan Symbolic Instruction Code Pemula. Untuk Itu kode program dalam Visual Basic menyerupai bahasa Inggris. Berbeda software perusahaan telah menghasilkan berbagai versi BASIC untuk DOS, seperti Microsoft QBASIC, QuickBasic, GWBASIC, dan IBM BASICA dan banyak lagi. Kemudian, Microsoft meluncurkan grafis pertama BASIC, Versi Visual Basic 1 pada tahun 1991. Hal ini berbasis GUI dan terutama dikembangkan untuk jendela MS. Sejak saat itu Microsoft perlahan dihapus DOS versi BASIC dan benarbenar menggantinya dengan Visual Basic. Visual Basic awalnya sebuah bahasa pemrograman prosedural atau fungsional sampai populer Visual Basic 6. Kemudian, Microsoft Visual Basic berubah menjadi lebih kuat berorientasi objek bahasa pemrograman Visual Basic.Net dengan meluncurkan, Visual Basic 2005, Visual Basic 2008 dan 2010 terbaru Visual Basic. Visual Basic
2008 merupakan Object-Oriented Programming fullfledged (OOP) Bahasa, telah tertangkap dengan lainnya OOP bahasa seperti $\mathrm{C}++$, Java, C \# dan lain-lain. Namun, Anda tidak perlu tahu OOP untuk belajar VB2010. Bahkan, jika Anda sudah familiar dengan Visual Basic6, Anda dapat belajar VB2010 mudah karena sintaks dan antarmuka yang hampir mirip.

Teknologi .NET adalah sebuah Platform baru yang dirilis oleh Microsoft. Teknologi ini memunculkan sebuah paradikma baru dalam pemrograman berbasis Windows. Ide dasar dari teknologi ini mungkin menyerupai apa yang sudah dilakukan oleh java, yaitu program yang dibuat dari system operesi Windows, yang nantinya juga dapat digunakan dalam system operasi lain, misalnya LINUX sehingga programmer dapat membuat program lebih efesien.

Teknologi .NET didasarkan atas susunan berupa .NETFramework. Setiap produk baru yang terkait dengan teknologi .NET akan selalu berkembang mengikuti perkembangan .NET Framwork.

Visual Studio hadir dengan beberapa versi, yaitu :

a. Team Sistem, didesain untuk pemrograman di lingkungan koorporasi dengan jumlah programmer yang besar.

b. Profesional Edition, didsain untuk pemrograman yang melibatkan sedikit programmer. 
c. Express Edition, didesain untuk pemula yang baru belajar dan hobi dengan fasilitas yang sangat terbatas.Visual Studio tidak hanya mendukung bahasa Visual Basic saja,namun juga bahasa lain. Terutama C++ dan C\#.

\subsubsection{Sekilas Mengenai MySQL}

MySQL adalah Relational Database Management Sistem (RDBMS) yang didistribusika secara gratis di bawah licensi GPL (GeneralPublic License). Dimana setiap orang bebas untuk menggunakan MySQL, namun tidak boleh dijadikan produk turunan yang bersifat close source atau komersial.

MySQL sebenarnya merupakan turunan salah satu konsep utama dalam database sejak lama yaitu, SQL (Structured Query Language). SQL adalah sebuah konsep pengoperasian database, terutam untuk pemilihan/seleksi dan pemasukan data, yang memungkinkan pengoperasian data dikerjakan dengan mudah secara otomatis. Keandalan suatu sistem database (DBMS) dapat diketahui dari cara kerja optimizer-nya dalam melakukan proses perintah perintah SQL, yang dibuat oleh user maupun program program aplikasinya. Sebagai databse server, MySQL dapat dikatakan lebih unggul dibandingkan database server lainnya dalam query data. Hal ini terbukti untuk query yang dilakukan oleh single user, kecepatan query MySQL bisa sepuluh kali lebih cepat dari PostgreSQL dan lima kali lebih cepat dibandingkan Interbase. Kemmpuan yang cukup menakjubkan untuk sebuah software gratisan.

MySQL adalah satu dari sekian banyak sitem database, merupakan terobosan solusi yang tepat dalam aplikasi database. Didukung oleh ribuan bahkan jutaan komunitas pengguna di internet yang siap membantu. Selain itu juga tersedia mailing list dan homepage khusus yang memberikan tutorial serta dokumen lengkap.

\section{HASIL DAN PEMBAHASAN}

\subsection{Desain Sistem}

Tujuan dari desain sistem adalah untuk mempercepat pengambilan keputusan, perincian-perincian yang mudah dipahami sehingga tidak terjadi kesalahan dalam menjalankannya. Desain sistem pada hakekatnya bukan hanya mempercepat atau mengoptimalisasikan kegiatan operasi dalam toko ini, tetapi juga mancakup standarisasi dengan hasil dalam penghematan waktu dan biaya. Desain sistem yang baru ini, akan dibagi kedalam dua kelompok sistem perancangan yaitu Desain Sistem Secara Global (Umum) dan Desain Sistem Secara Terinci (Khusus).

Agar perubahan sistem yang dilakukan dapat menunjang terhadap sistem yang sedang berjalan, maka ada beberapa hal yang harus diperhatikan yaitu :

1. Output yang dihasilkan dari pengolahan data pada sistem yang baru harus lebih baik dari sistem lama.

2. Memberikan kemudahan dan kenyamanan bagi semua pihak yang terlibat dalam sistem baru, 


\section{Jurnal Edik Informatika E-ISSN : 2541-3716}

Penelitian Bidang Komputer Sains dan Pendidikan Informatika

V1.i2(37-47)

yaitu dengan rendahnya tingkat kerumitan proses yang harus dilakukan dalam menghasilkan sebuah informasi.

3. Biaya yang akan dikeluarkan oleh sistem baru haruslah lebih kecil dibandingkan dengan sistem lama.

\subsubsection{Desain Input}

Desain input merupakan rancangan form untuk memasukkan data kedalam database, sehingga bisa menghasilkan laporan-laporan yang dibutuhkan.

Adapun bentuk dari desain input yang dirancang pada pengontrolan ruang inap adalah :

1. DesainInput Data Kamar

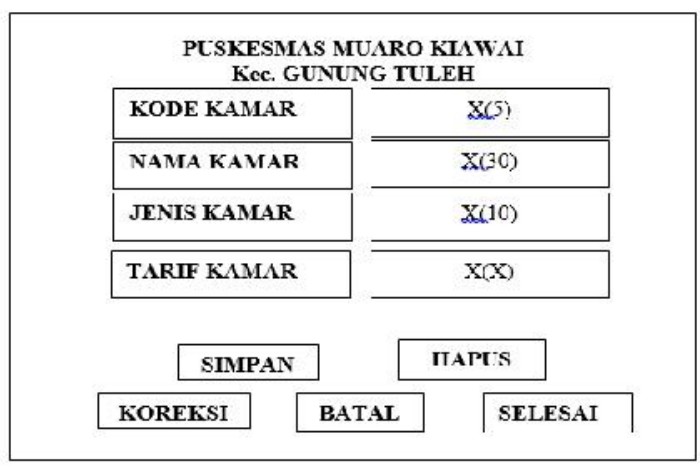

2. DesainInput Data Pasien

\begin{tabular}{|c|c|}
\hline \multicolumn{2}{|c|}{$\begin{array}{l}\text { PUSKFSMAS MUAKO KIAWNI } \\
\text { KEC. GUNUNG TULEII }\end{array}$} \\
\hline VOMOR RFG:TSTRAST & $x(10)$ \\
\hline NAMA PASIEN & $x(30)$ \\
\hline TFNTS KFI.AMTN & $x(x)$ \\
\hline LMUR & $x_{0}(8)$ \\
\hline ALAMAT & $x(30)$ \\
\hline TANGFAT, MASTIK & $x(x)$ \\
\hline STMPAN & HAPUIS \\
\hline KOR & SFIFSAI \\
\hline
\end{tabular}

3. DesainInput Data Dokter

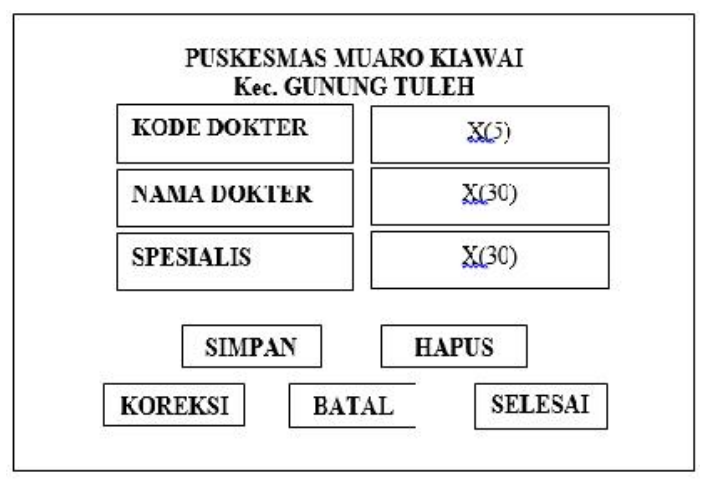

\subsection{Desain Output}

Desain output adalah rancangan bentuk informasi yang akan dihasilkan pada sistem. Desain output merupakan hal yang paling penting sekali, karena laporan atau keluaran yang dihasilkan harus memudahkan bagi setiap user yang membutuhkannya. Desain output ini merupakan pengembangan dari bentuk output pada system sedang dipakai. Adapun bentuk output yang di rancang dalam pengontrolan ruang inap adalah sebagai berikut :

\section{Laporan Data Kamar}

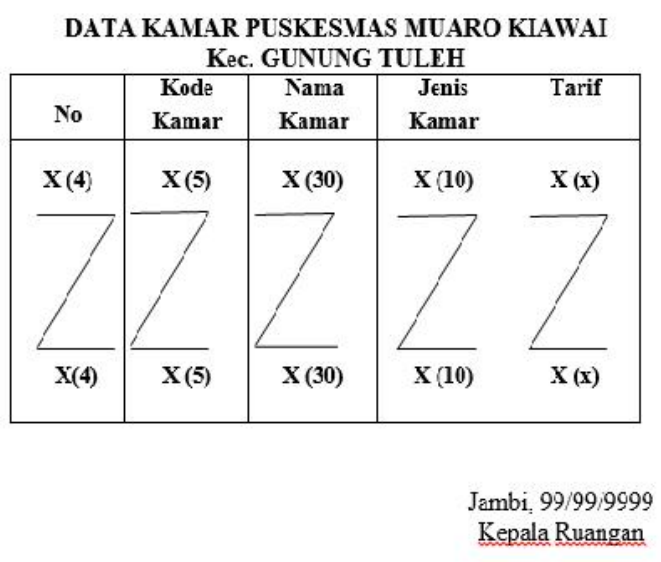


2. aporan Data Pasien

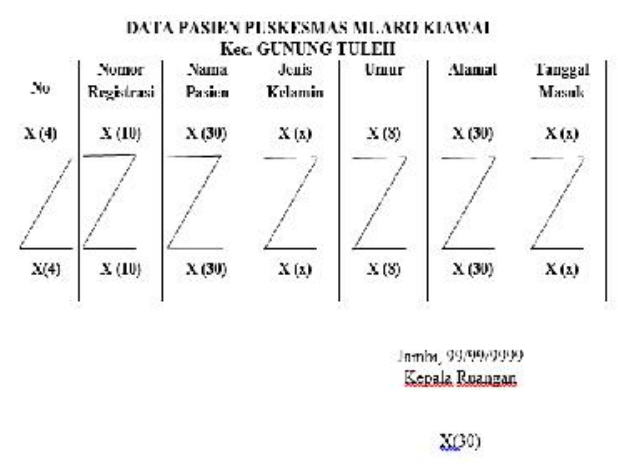

3. Laporan Data Dokter

\section{DATA DOKTER PUSKESMAS MLARO KIAWAI} Kec. GUNUNG TULEH

\begin{tabular}{|c|cc|c|}
\hline No & $\begin{array}{c}\text { Kode } \\
\text { Dokter }\end{array}$ & $\begin{array}{c}\text { Nama } \\
\text { Dokter }\end{array}$ & Spesialis \\
\hline${ }^{\mathbf{X}(4)}$ & $\mathbf{X}(5)$ & $\mathbf{X}(\mathbf{3 0})$ & $\mathbf{X}(\mathbf{3 0})$ \\
\hline & & & \\
\hline $\mathbf{X}(4)$ & $\frac{X(5)}{X(30)}$ & $\mathbf{X}(\mathbf{3 0})$ \\
\hline
\end{tabular}

Jambi, 99/99/9999 Kepala Ruangan

$\mathrm{x}(30)$

\section{HASIL DAN PENGUJIAN}

\subsection{Implementasi Sistem}

Implementasi sistem adalah sistem yang siap pakai untuk diterapkan pada sebuah perusahaan yang telah diteliti. Sebelum diimplementasikan secara langsung pada perusahaan perlu dilakukan pengujian terlebih dahulu.

\subsubsection{Tujuan Implementasi Sistem}

Adapun tujuan dari implementasi sistem sebagai berikut :

a. Menguji serta mendokumentasikan prosedur dan program yang diperlukan oleh dokumen sistem yang telah dibuat.

b. Menyelesaikan desain sistem yang ada dalam sistem desain baru yang disetujui.

c. Memperhitungkan sistem yang telah dibuat sesuai kebutuhan user.

\subsubsection{Pemeliharaan Sistem}

Tahap ini menekankan kepada pemeliharaan sistem yang lebih mengarah kepada manajemen sistem. Untuk itu seorang sistem analis juga harus memikirkan apa tindakan yang terbaik yang perlu dilakukan dalam pemeliharaan suatu sistem.

Pemeliharaan sistem sangat penting dilakukan agar data dan informasi yang telah terhimpun tetap terjaga. Pemeliharaan sistem secara rutin dapat meliputi penataan ulang database, membackup dan scanning virus. Sementara itu, pemeliharaan juga termasuk melakukan penyesuaianpenyesuaian untuk menjaga kemutakhiran sistem atau pembetulan atas kesalahankesalahan yang mungkin terjadi dan belum diketahui sebelumnya.

\subsection{Pengujian Sistem}

Pengujian sistem dilakukan agar mengetahui sejauh mana program bebas dari kesalahan sebelum program diterapkan. Setelah program pengujian selesai dilakukan maka akan didapat hasil 


\section{Jurnal Edik Informatika E-ISSN : 2541-3716}

Penelitian Bidang Komputer Sains dan Pendidikan Informatika

V1.i2(37-47)

dari pengujian tersebut. Adapun hasil pengujian adalah sebagai berikut :

a. Entry Data Kamar

File data Kamar terdiri dari :Kode

Kamar, Nama Kamar, Jenis Kamar, Tarif

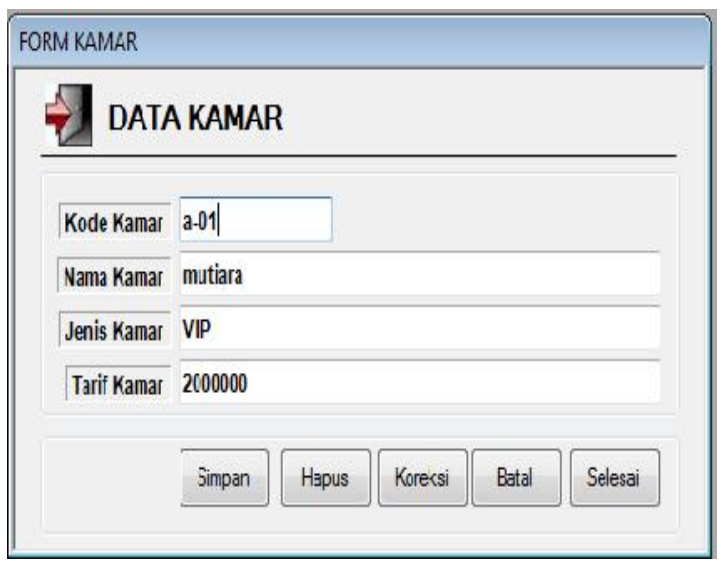

Gambar 5.4 Form Data Kamar

\section{b. Entry Data Pasien}

File data Pasien terdiri dari : Nomor Registrasi, Tanggal Masuk, Nama Pasien, Umur, Jenis Kelamin, Alamat

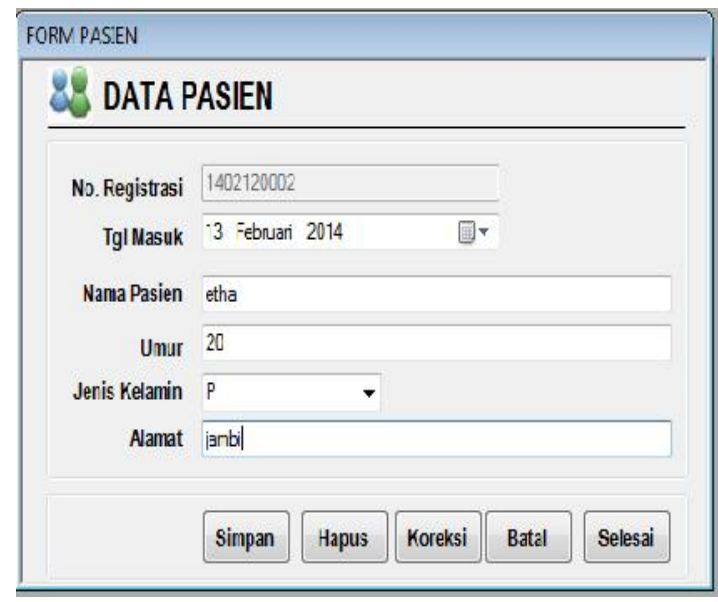

Gambar 5.3 Form Data Pasien

\section{c. Entry Data Dokter}

File data Dokter terdiri dari : Kode Dokter, Nama Dokter, Spesialis.

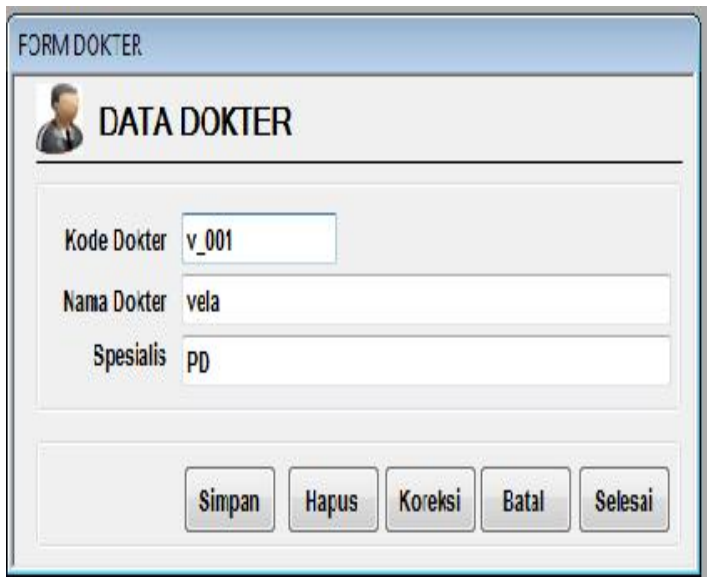

Gambar 5.2 Form Data Dokter

d. Laporan Daftar Kamar Form Cetak Daftar Kamar

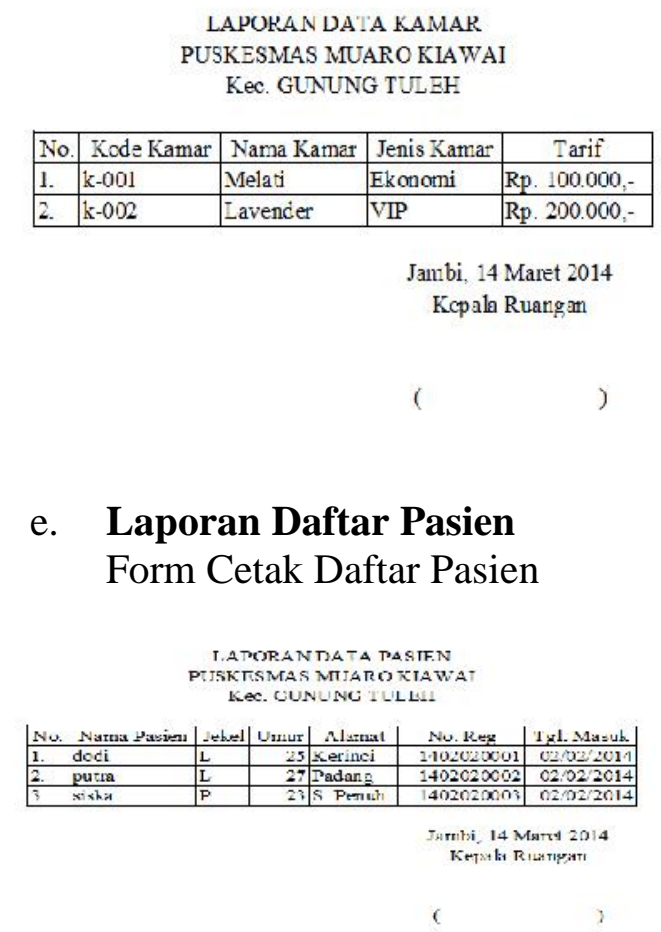




\section{f. Laporan Daftar Dokter} Form Cetak Daftar Dokter

LAPORAN DATA DOKTER

PUSKESMAS MUARO KIA WAI Kec. GUNUNG TULEH

\begin{tabular}{|l|l|l|l|}
\hline No. & Kode Dokter & Nama Dokter & Spesialis \\
\hline 1. & d-001 & elviza rahma & gigi \\
\hline 2. & d-002 & tonny hartono & jantung \\
\hline \multicolumn{4}{|c}{ Jambi, 14 Maret 2014 } \\
Kepala Ruangan
\end{tabular}

\section{KESIMPULAN DAN SARAN-SARAN}

\subsection{Kesimpulan}

Setelah melakukan penelitian pada Puskesmas Muaro Kiawai Kec. Gunung Tuleh, menganalisa sistem pendaftaran dan penerimaan pasiennya dan dilanjutkan dengan perancangan sistem informasi maka dapat diperoleh beberapa kesimpulan sebagai berikut :

1. Dalam melakukan pengolahan data kamar, pasien dan dokter masih dilakukan secara manual sehingga laporan yang dihasilkan kurang bersih karena banyaknya terdapat coretan.

2. Dengan menggunakan sistem baru, pembuatan laporan kamar, laporan pasien dan laporan dokter hanya diperlukan waktu kurang dari 1 jam saja sedangkan dalam sistem lama memerlukan waktu lebih kurang 2 jam.

3. Pengolahan data dalam sistem baru menggunakan suatu database yang terdiri dari 3 tabel dimana database tersebut dapat dilakukan manipulasi seperti: menambah data, mengedit data dan menghapus data.

4. Sistem baru ini dapat dijalankan dengan menggunakan program aplikasi Visual Basic yang bersifat user friendly.

\subsection{Saran - saran}

Adapun saran-saran yang dikemukakan sehubungan dengan sistem baru yang dirancang adalah :

1. Dalam penerapan sistem baru ini, perlu dilakukan pelatihan terhadap karyawan untuk menghindari terjadinya kesulitan dan kesalahan-kesalahan dalam pengoperasian sistem.

2. Ketelitian dan kecermatan dibidang komputer harus diperhatikan dengan sungguhsungguh dan diperlukan tenaga ahli yang terampil baik dalam pengoperasian maupun pengontrolan hardware.

3. Kerjasama sangat dibutuhkan untuk mencapai tujuan serta didukung oleh informasi yang terbaru dan lancar sehingga keputusan yang diambil lebih tepat.

4. Sistem baru ini dapat dioperasikan secara optimal, maka cara kerja dari sistem lama dapat ditinggalkan secara bertahap sesuai dengan kondisi yang ada pada Puskesmas Muaro Kiawai Kec. Gunung Tuleh untuk meningkatkan produktivitas kerja. 
5. Sistem baru ini merupakan desain sistem yang mampu menghasilkan laporan dan informasi yang akurat, namun demikian perlu ketelitian dan kecermatan dalam penerapannya karena jika terjadi satu kesalahan akan mempengaruhi data yang lain.

\section{DAFTAR PUSTAKA}

Binanto, Iwan. (2005). Konsep Bahasa Pemrograman. Yogyakarta: Andi Offsed.

Jogiyanto.(2005) Analisa dan Desain Sistem Informasi. Yogyakarta : Andi.

Jogianto, H.M. (2001). Analisa \& Desain Sistem Informasi . Yogyakarta : Andi Offset.

Jogianto, HM. (2003). Pengantar Database. Ditemukan tanggal 11 Juni 2009. dari http://wwww.sqlcourse.com.
Kadir, Abdul. (2000). Konsep \& Tuntunan Praktis Basis Data. Yogyakarta: Andi Offset.

Kadir, Abdul. (2003).Pengenalan Sistem Informasi. Yogyakarta : Andi Offset.

Nugroho,Bunafit.(2009). Tugas Akhir Membuat Aplikasi Penjualan Barang dengan Visual Basic 6.0. Yogyakarta : Alif media.

Nugroho, Bunafit. (2008). Buku Wajib : Menguasai Perintah SQL. Jakarta : MediaKita.

Nugroho, Bunafit. (2007). Sistem Informasi Penjualan Retail dengan SQL Server dan Visual Basic 6.0. Jakarta : Elex Media.

Oetomo, Budi Sutedjo Dharma. (2002). Perencanaan \& Pembangunan Sistem Informasi. Yogyakarta: Andi Offset.

Swatika,Windra. (2008). VB dan Mysql. Yogyakarta: Dian Rakyat. 